\title{
pÿRecycling sludge on cropland as fertilizer advantages and risks
}

\section{Seleiman, Mahmoud}

2020-04

Seleiman , M , Santanen , A \& Mäkelä , P 2020 , ' Recycling sludge on cropland as fertilizer

pÿ advantages and risks ' , Resources, Conservation and Recycling , vol. 155 , 104647 . https://doi.org/10.1016/j.re

http://hdl.handle.net/10138/337795

https://doi.org/10.1016/j.resconrec.2019.104647

cc_by_nc_nd

acceptedVersion

Downloaded from Helda, University of Helsinki institutional repository.

This is an electronic reprint of the original article.

This reprint may differ from the original in pagination and typographic detail.

Please cite the original version. 


\section{Recycling sludge on cropland as fertilizer - advantages and risks}

2 Mahmoud F. Seleiman ${ }^{\mathrm{a}, *, \dagger}{ }^{\dagger}$, Arja Santanen ${ }^{\mathrm{b}}$, Pirjo S.A. Mäkelä

3 aPlant Production Department, College of Food and Agriculture Sciences, King Saud 4 University, P.O. Box 2460, Riyadh 11451, Saudi Arabia

$5 \quad{ }^{b}$ Department of Agricultural Sciences, P.O. Box 27, 00014 University of Helsinki, Finland 6 *Corresponding author: Dr. Mahmoud F. Seleiman, Tel: +966553153351, E-mail address:

7 mseleiman@ksu.edu.sa

$8 \quad$ Permanent Affiliation: Department of Crop Sciences, Faculty of Agriculture, Menoufia

9 University, 32514 Shibin El-kom, Egypt

\section{Abstract}

Background Digested sludge is a good source of plant nutrients. However, depending on the feedstock, it might contain heavy metals, metalloids, organic compounds, pathogens, and pharmaceuticals, which can cause adverse effects on crop growth and contaminate the groundwater, soil, and food chain.

Scope The aim of this review is to focus on the potential risks of inorganic and organic contaminants to plant growth, soil, groundwater, and consequently the food chain and environment related to the utilization of digested sludge as a fertilizer on cropland.

Conclusions Inorganic compounds, such as metals and metalloids, in sludge can occasionally cause reductions in soil microbial biomass. In general, the uptake of metals and organic contaminants does not appear to cause a significant hazard to the plants and the concentrations do not surpass the maximum values allowed in soil. Organic compounds, 
harmful for human health or the environment, are to a large extent decomposed or volatilized from the land treated with sludge, which decreases their leaching into the environment. Many of the organic compounds are lipophilic and can be bound to soil organic matter. In conclusion, the application of sludge on cropland might be a sustainable management practice; however, further investigations are needed to determine the accumulation and persistence of possible hazardous emerging chemicals and pathogens in the environment and formation of harmful intermediate reaction of inorganic and organic compound products.

Keywords Digestate, Food chain, Nutrient cycling, Pollutants, Sustainable agriculture

\section{Introduction}

The global population has increased rapidly from 5.3 billion in 1992 to 7.6 billion in 2018 and will reach 9.9 billion in 2050 (World Population Data Sheet, 2018). Such a rapid population growth will cause an increase in the consumption of water globally and consequently increase wastewater production along with digested sewage sludge, which represents about $0.3-0.5 \%$ of treated wastewater ( $\mathrm{Li}$ et al., 2011). The disposal of digested sludge (herein sludge) in a safe way is a major environmental concern all over the world. The application of sludge on land after appropriate processing would support increased sustainability of agricultural production, as it recycles the nutrients back to the soil and makes them available to plants (Petersen et al., 2003; Antoline et al., 2005; Bozkurt et al., 2006; Seleiman et al. 2012, 2013a, 2013b; Bai et al., 2017; Seleiman et al., 2017).

Sludge is a solid or semi-solid by-product of domestic, industrial, and storm wastewaters treated through aerobic or anaerobic digestion processes in wastewater treatment plants (WWTPs) (Gardiner et al., 1995; Rogers, 1996; Andersen, 2001; Epstein, 2003; Harrison et 
al., 2006; Bianchini et al., 2016; Lovingood et al. 2018; Saleh Bairq et al., 2018). Sludge may also contain some inputs from farms, such as plant residues and manure (Fytili and Zabanioto, 2008; Seleiman et al., 2013a). The processing of wastewater includes primary (i.e., physical and/or chemical), secondary (i.e., biological), and finally tertiary (i.e., nutrient removal) treatments (Fytili and Zabanioto, 2008). Aerobic digestion is a process with a retention period of 7 days during which the sludge is subjected to at least $55{ }^{\circ} \mathrm{C}$ for an adequate period to ensure that the composting process is completed. In anaerobic digestion, primary digestion of 12 days at $35{ }^{\circ} \mathrm{C}$ or 24 days at $25{ }^{\circ} \mathrm{C}$ is followed by a retention period of at least 14 days (Tchobanoglous and Burton, 1991).

The use of sludge as a fertilizer can reduce the need for synthetic inorganic fertilizers (Seleiman et al., 2013a; Urbaniak et al., 2017) and can provide some micronutrients that are otherwise not added to the soil (Seleiman et al., 2012, 2013a, 2013b). Moreover, using sludge as a source of nutrients in agriculture can save non-renewable sources of energy for more sustainable production (Seleiman et al., 2013a; Urbaniak et al., 2017). Anaerobic digestion of wastewater sludge also produces methane, a valuable biofuel (Berktay and Nas, 2008; Gilbert et al., 2011). Sludge can be used as an alternative to synthetic fertilizers, for example for bioenergy crops (Seleiman et al., 2012, 2013a, 2013b; Urbaniak et al., 2017). This alternative use not only acts as an efficient method of sludge management, but is also in line with the implementation of the renewable energy directive 2009/28/EC, which requires $20 \%$ of total energy to be obtained from renewable sources in the European Union (EU) (Urbaniak et al., 2017). 
In addition to beneficial plant nutrients, sludge may contain a variety of inorganic and organic substances, pharmaceuticals, and pathogens depending on the inputs of effluents in the wastewater plants and types of digestion used in the process (Carrington, 2001; Urbaniak et al., 2017; Hudcová et al., 2019). For instance, anaerobic digestion or even aerobic composting of sludge can be the main cause of organic contaminants, since the substances in the sludge may be partially biodegradable and new toxic intermediates can be formed (Schowanek et al., 2004). The main part of organic materials in sludge comes from human fecal material, but industrial catchment wastewaters can also be a source of organic material in sludge (Rogers, 1996; Andersen, 2001).

The benefits of adding any sludge as fertilizer to cropland must be compared with the risks of any contamination of the food chain by harmful substances that the sludge may contain and any leaching of the contaminants or plant nutrients to the environment. The awareness regarding inorganic and organic pollutants in food chain is increasing constantly, though knowledge gaps still remain. Therefore, it is of utmost importance to update the knowledge related to emerging and existing pollutants especially in sludge, since the interest to recycle it in croplands is constantly increasing. This article reviews the current understanding of the major risks to the food chain and the environment related to the use of sludge in agricultural soils.

\section{Production and disposal of sludge}

The alternatives for the disposal of sludge are agricultural use, composting, incineration, and landfill (Epstein, 2003; EUROSTAT, 2018; Hudcová et al., 2019). In the past, agricultural use (37\% of the sludge produced in Europe) and landfill (40\%) were considered the most 
economical options for sludge disposal (Tchobanoglous and Burton, 1991; Fytili and Zabaniotou, 2008), followed by incineration (11\%) and some other uses (12\%) such as forestry and land reclamation (Fytili and Zabaniotou, 2008). However, incineration (39\%)

91 and agricultural use (25\%) are considered the main methods of sludge disposal in the EU 92 nowadays, followed by composting (15\%), other uses (13\%), and finally landfill $(8 \%)$ 93 (EUROSTAT, 2018; Hudcová et al., 2019). In 2015, half or more of the sludge produced in 94 Ireland (80\%), Albania (77\%), UK (74\%), Spain (70\%), Norway (62\%), and Bulgaria (53\%) 95 was applied to cropland, whereas less than $5 \%$ of the sludge produced in Finland and 96 Romania, and none in Greece, Slovenia, Slovakia, and Malta, was applied to cropland 97 (Figures 1, 2) (EUROSTAT, 2018; Hudcová et al., 2019).

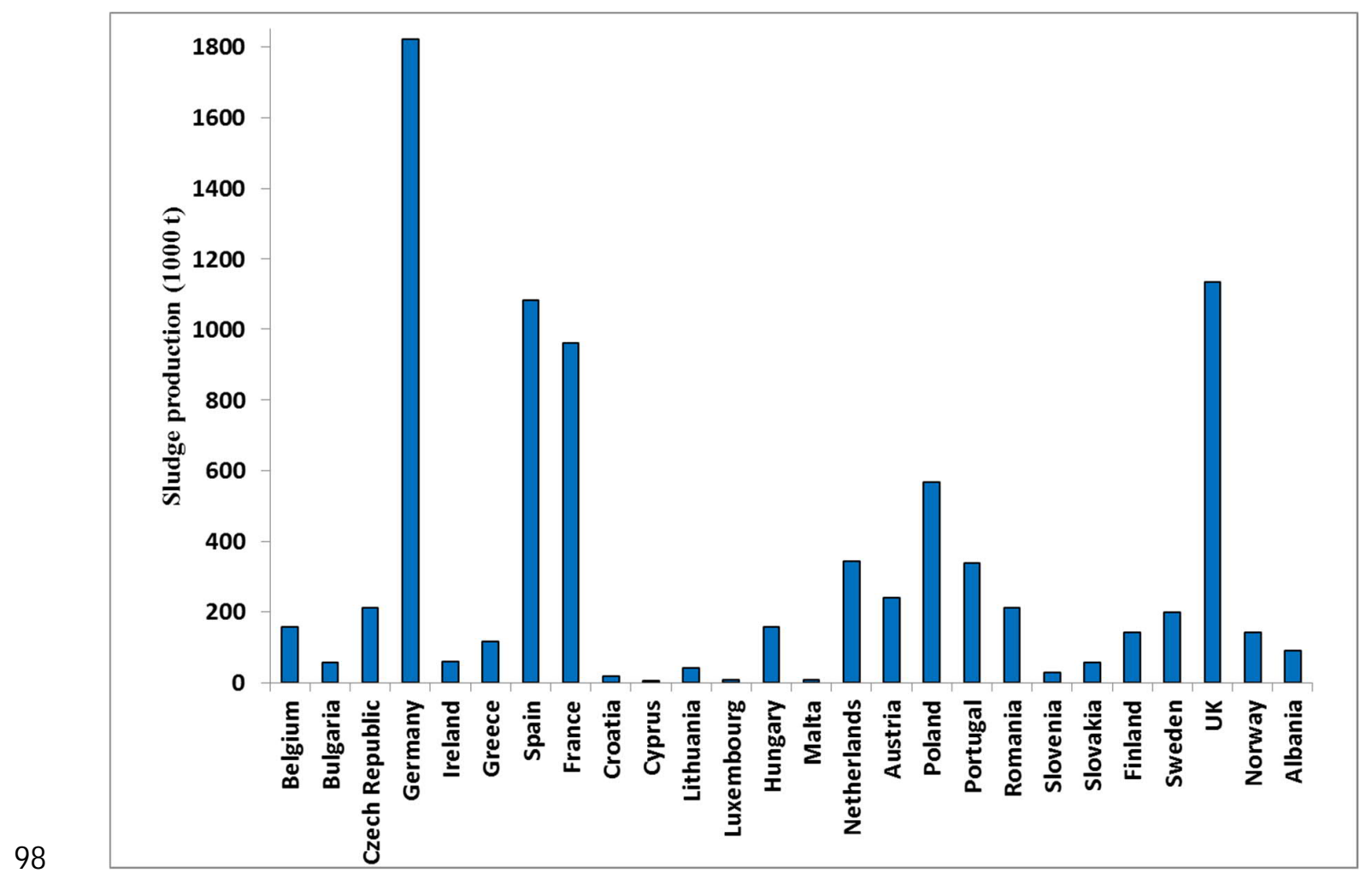

$99 \quad$ Figure 1 


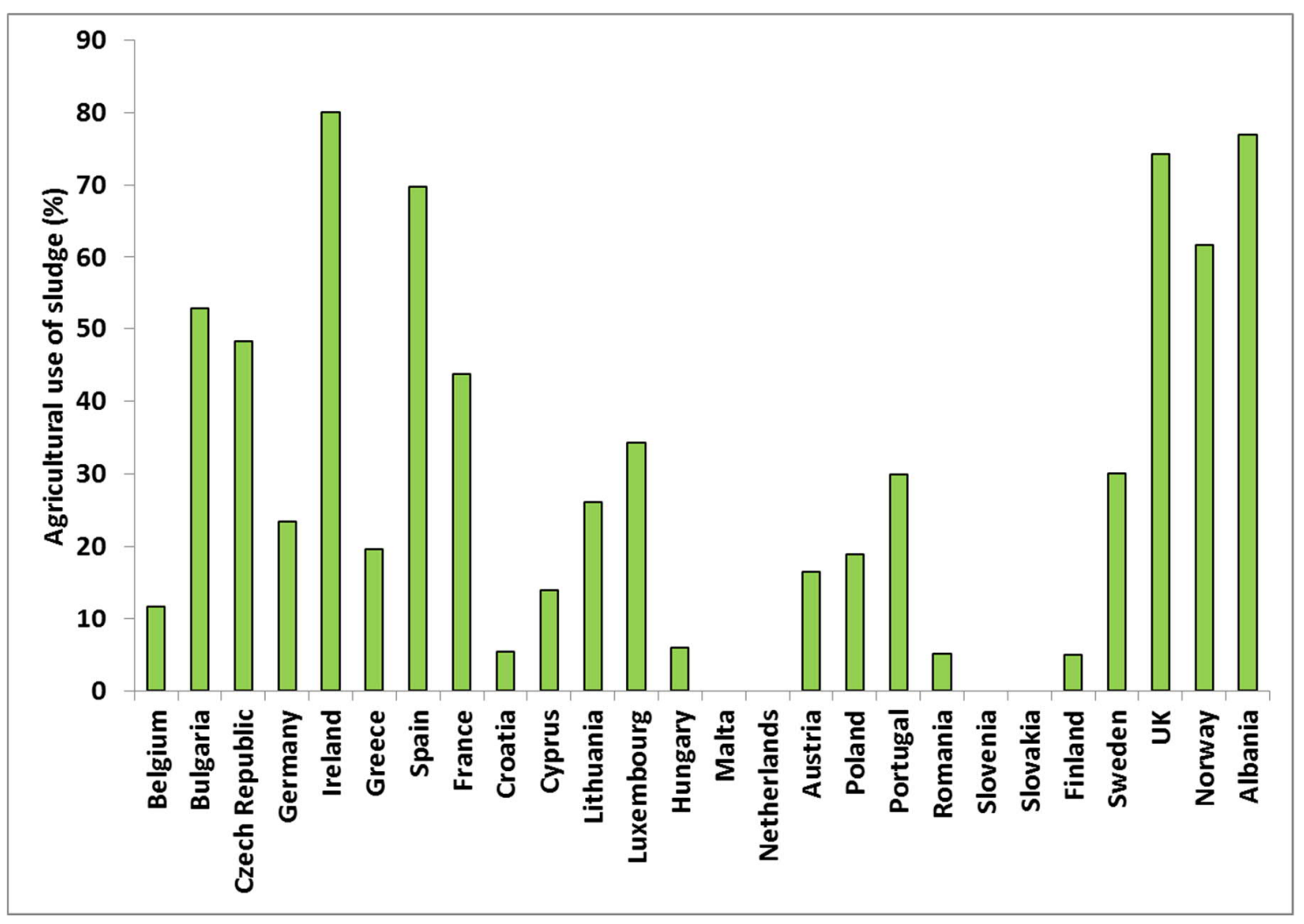

Figure 2

Agricultural use (\%) of sludge in the European Union during 2012 - 2015 (EUROSTAT, 2018).

\section{Composition of sludge}

\subsection{Inorganic compounds in sludge}

108 Sludge contains nutrients, heavy metals, and metalloids (Seleiman et al., 2012, 2013a,

109 2013b; Bai et al., 2017; Fijalkowski et al., 2017; Rehman et al., 2018; Wang et al., 2018),

110 some of which are essential macronutrients, such as nitrogen $(\mathrm{N})$, phosphorus $(\mathrm{P})$, potassium 
$111(\mathrm{~K})$, calcium $(\mathrm{Ca})$, and manganese $(\mathrm{Mn})$, and some are essential trace elements, such as 112 boron $(\mathrm{B})$, copper $(\mathrm{Cu})$, iron $(\mathrm{Fe})$, nickel $(\mathrm{Ni})$, and zinc $(\mathrm{Zn})$ (Table 1) (Epstein, 2003;

113 Bozkurt et al., 2006; Kidd et al., 2007; Yan et al., 2009; Du et al., 2012; Gu et al., 2013;

114 Seleiman et al., 2013a, 2017). However, at excessive concentration even the essential 115 elements can be toxic similarly to non-beneficial heavy metals, such as cadmium (Cd), 116 chromium $(\mathrm{Cr})$, arsenic (As), and lead (Pb) (Pepper et al., 2006; Singh and Agrawal, 2008; 117 Yan et al., 2009; Seleiman et al., 2013a).

118 The nutrient content of sludge varies markedly depending on the source of the wastewater, 119 its treatment, as well as the sludge treatment and feedstock used (Table 1). Sludge can 120 contain inorganic and organic $\mathrm{N}$ up to $51 \mathrm{~g} \mathrm{~kg}^{-1}$ dry matter (DM), and inorganic and organic 121 P up to $28 \mathrm{~g} \mathrm{~kg}^{-1} \mathrm{DM}$ (Yan et al., 2009; Seleiman et al., 2012, 2013a, 2013b; Gu et al., 2013). 122 The bioavailability of $\mathrm{P}$ in sludge ranges from 40 to $80 \%$ (Andreoli et al., 2007), whereas 123 the efficiency of synthetic P fertilizers is markedly lower, mostly due to the high soil capacity 124 for fixing P (Mooso et al., 2013; Hudcová et al., 2019). In sludge, the content of K is much 125 lower (less than $5 \mathrm{~g} \mathrm{~kg}^{-1} \mathrm{DM}$ ) than the content of $\mathrm{N}$ and $\mathrm{P}$ due to their high solubility 126 (Antoline et al., 2005; Seleiman et al., 2013a). K compounds become mainly dissolved in 127 the wastewater and do not settle with the sludge (Epstein, 2003; Yan et al., 2009). The 128 content and bioavailability of $\mathrm{N}$ and $\mathrm{P}$ in sludge depends on the precipitation chemicals and 129 the procedure used for cleaning wastewater (Table 1). As a comparison with other commonly 130 utilized organic nutrient sources, animal manure (including decomposed straw, feces, and 131 urine) contains approximately $1.2 \% \mathrm{~N}, 1.3 \% \mathrm{P}, 1.5 \% \mathrm{~K}, 1.5 \% \mathrm{Mg}$, and $4.5 \% \mathrm{Ca}$, in addition 
132 to other nutrients (Xu et al., 2017), and meat-bone meal contains approximately $8.0 \% \mathrm{~N}$, $1334.4 \% \mathrm{P}, 4.5 \% \mathrm{~K}, 1.5 \% \mathrm{Mg}$, and $10.0 \% \mathrm{Ca}$ (Vamvuka et al., 2018). 
Table 1

135 Examples of chemical properties of sludge of different origins. In Seleiman et al. (2013a), sludge was based either purely on

136 sewage sludge or on sewage sludge digested with different feedstock materials like food leftovers and manure

\begin{tabular}{|c|c|c|c|c|c|c|c|}
\hline \multirow[b]{3}{*}{$\mathrm{pH}$} & \multirow{2}{*}{$\begin{array}{c}\begin{array}{c}\text { Pure sewage } \\
\text { sludge }\end{array} \\
\text { Seleim }\end{array}$} & \multirow{2}{*}{$\begin{array}{l}\text { Digested sludge } \\
\text { tal. (2013a) }\end{array}$} & \multicolumn{5}{|c|}{ Sewage sludge } \\
\hline & & & \multirow{2}{*}{$\begin{array}{c}\text { Antoline et al. } \\
(2005)\end{array}$} & \multirow{2}{*}{$\begin{array}{c}\text { Kidd et al. } \\
(2007) \\
12.0\end{array}$} & \multirow{2}{*}{$\begin{array}{r}\begin{array}{l}\text { Gu et al. } \\
(2013)\end{array} \\
6.3\end{array}$} & \multirow{2}{*}{$\begin{array}{c}\text { Grobelak et al. } \\
(2017)\end{array}$} & $\begin{array}{c}\text { Urbaniak et al } \\
\text { (2017) }\end{array}$ \\
\hline & 7.2 & 6.9 & & & & & \\
\hline $\mathrm{C}: \mathrm{N}$ & & & & 9.5 & & 47.4 & \\
\hline \multicolumn{8}{|c|}{$\mathrm{g} \mathrm{kg}^{-1}$ DM } \\
\hline $\mathrm{N}$ & 31.0 & 7.4 & 22.2 & 20.0 & 51.2 & 14.5 & 15.7 \\
\hline $\mathrm{C}$ & & & & 190.0 & & 690.0 & \\
\hline $\mathrm{P}$ & 26.0 & 9.9 & 16.6 & & 5.51 & 3.5 & 13.3 \\
\hline K & 2.1 & 1.1 & 4.7 & & & & \\
\hline \multicolumn{8}{|c|}{$\mathrm{mg} \mathrm{kg}^{-1} \mathrm{DM}$} \\
\hline $\mathrm{Mn}$ & 220.0 & 56.9 & 226.0 & 350.0 & 130.0 & & \\
\hline $\mathrm{Cd}$ & 0.4 & $<0.5$ & 3.0 & 5.0 & 3.3 & 1.7 & 1.36 \\
\hline $\mathrm{Cr}$ & 30.0 & 11.0 & 52.0 & 115.0 & 156.0 & & 37.2 \\
\hline $\mathrm{Cu}$ & 270.0 & 88.0 & 205.0 & 230.0 & 1120.0 & & 55.8 \\
\hline $\mathrm{Pb}$ & 20.0 & 4.9 & 80.5 & 69.0 & & 149.0 & $\leq 26.1$ \\
\hline $\mathrm{Ni}$ & 20.0 & 5.5 & 25.0 & 35.0 & 52.8 & & $\leq 10.4$ \\
\hline $\mathrm{Zn}$ & 470.0 & 130.0 & 731.0 & 500.0 & 30.0 & 288.9 & 344.8 \\
\hline As & 5.0 & 1.3 & & & & & \\
\hline
\end{tabular}


138

139

140

141

142

143

144

145

146

147

148

149

150

151

152

153

154

155

156

157

158

159

\subsection{Organic compounds in sludge}

Approximately 145297 chemicals are preregistered in the European Chemicals Agency for industrial, agricultural, and household use (European Chemicals Agency, 2018). In the course of time, many of these substances will enter wastewater systems, where incompletely removed, hydrophobic compounds potentially remain in solid matter during water purification processes (Smith, 2009). In surveys from European and North American WWTPs, concentrations of organic compounds have varied from less than $\mathrm{ng}$ to $\mathrm{g} \mathrm{kg}^{-1} \mathrm{DM}$ of sludge depending on the source and processing techniques (Clarke and Smith, 2011). Regulations have decreased the concentration of most persistent, hazardous organic compounds in wastewaters, and they are no longer considered obstacles to the utilization of sludge in agriculture (Harrison et al., 2006).

Volatilized and biodegraded organic compounds can partially be lost through different treatment processes in wastewater plants via leaching, volatilization, and chemical and biological degradation in anaerobic or aerobic digestion (Smith and Riddell-Black, 2007). Nevertheless, anaerobic digestion and composting have not met in all cases the requirements and fixed limit concentrations set by the EU for the most commonly found organic pollutants in sludge, i.e., di-(2-ethylhexyl)phthalate (DEHP), nonylphenol ethoxylates (NPEs), linear alkylbenzene sulfonates (LASs), polychlorinated biphenyls (PCBs), polynuclear aromatic hydrocarbons (PAHs), and polychlorinated dibenzo-p-dioxins and -furans (PCDD/Fs) (Stevens et al., 2003; Ahel et al., 1994). For example, surfactants LAS and NPE, and plasticizer DEHP, are aerobically biodegradable, but they are not degradable in mesophilic or thermophilic anaerobic digestion (Scott and Jones, 2000; IC Consultants, 2001). 
160 Composting has been shown to reduce LAS compounds by 77-91\% (Brunner et al., 1988;

161 Pakou et al., 2009). Surfactants are amphiphilic and can be adsorbed into the organic matter

162 of sludge and in addition metal ions may precipitate them into particulate matter, which is

163 usually sedimented in WWTP settling tanks when they are not available for degrading

164 microorganisms (Scott and Jones, 2000). PAHs, PCBs, and PCDD/Fs are hydrophobic and

165 have low biodegradability. Thus, they tend to adsorb and accumulate in solid sludge

166 (Fijalkowski et al., 2017; Hudcová et al., 2019). However, in aerobic soil environment

167 surfactants may undergo further degradation (Scott and Jones, 2010).

168 Most pharmaceuticals found in influent are also present in sludge. Especially high

169 concentrations of anti-inflammatory drug ibuprofen and some estrogens are adsorbed up to

170 few $\mathrm{mg} \mathrm{kg}^{-1} \mathrm{DM}$ on sludge (Martín et al., 2012; Jelic et al., 2011). Degradation of

171 pharmaceuticals in sewage treatment processes varies greatly: 41 pharmaceuticals from 21

172 different therapeutic groups accumulated in sludge up to concentrations of $100 \mathrm{ng} \mathrm{g}^{-1} \mathrm{DM}$

173 (Jelic et al., 2011). Quite high concentrations of antimicrobial fluoroquinolones (e.g. $426 \mu \mathrm{G}$

$174 \mathrm{~kg}^{-1}$ Ciprofloxacin) are also known to adsorb into sludge, though those will be degraded in

175 composting (Mitchell et al., 2015; Lillenberg et al., 2010).

176 Advanced oxidation technologies are proved to be promising methods to decompose organic

177 pollutants from wastewater. Chemical, photochemical, sonochemical (ultrasound) and 178 electroochemical processes either individually or in different combinations based in

179 formation of very reactive, non-selective hydroxyl radicals initiate oxidative cascade leading

180 to mineralization of organic pollutants to $\mathrm{CO}_{2}$ and $\mathrm{H}_{2} \mathrm{O}$ (Vanraes et al. 2016, Deng and Zhao

1812015 , Segneanu et al. 2013). 
New biotechnological approaches have also been studied to degrade organic pollutants from the wastewaters and sludge. White-rot fungus (Trametes versicolor L.) is known to catalyze degradation of phenolic compounds (Addorisio et al., 2013; Catapane et al., 2013) as well as catabolize organic pollutants in non-sterile urban and hospital wastewater (Cruz-Morató et al., 2013) and sludge (Rodríquez-Rodríquez et al., 2011, 2012, 2014). However, in some cases new toxic intermediate compounds may form in catabolic reactions (RodríquezRodríquez et al., 2012).

\subsection{Pathogens in sludge}

Sludge may also contain pathogens, such as bacteria, viruses, protozoa, and eggs of parasitic worms (Epstein, 2003; Yan et al., 2009; Urbaniak et al., 2017). Plant-based sludge could contain plant pathogens, such as viruses, bacteria, fungi, and parasites, along with undesired weed seeds (Carrington, 2001). Sludge of animal origin, such as from livestock production, slaughterhouses, or meat processing industries, could contain antibiotic resistant bacteria and viruses (Franke-Whittle and Insam, 2013). Slaughter wastes may also contain the prions of bovine spongiform encephalopathy (Carrington, 2001; Franke-Whittle and Insam, 2013). Typical concentrations of colony forming units of most common bacteria in untreated sludge are $10^{2}$ to $10^{3} \mathrm{~g}^{-1} \mathrm{DM}$ of Salmonella spp. to $10^{6} \mathrm{~g}^{-1}$ of Escherichia coli, $10^{2}$ to $10^{4} \mathrm{~g}^{-1}$ of enteroviruses, $10^{2}$ to $10^{3} \mathrm{~g}^{-1}$ of protozoa, and 5 to $10^{3} \mathrm{~g}^{-1}$ of helminth eggs (Carrington, 2001). To produce sludge for safe use as fertilizer in agriculture, the treatment must reduce the number of Salmonella spp. and enteroviruses by at least four orders of magnitude as well as destroy the viability of Ascaris and helminths' ova. In addition, the level of Escherichia coli should not exceed 1000 colony forming units $\mathrm{g}^{-1} \mathrm{DM}$ sludge, and the level of 
205 (Strauch, 1998).

206 Pathogen level and diversity in wastewater vary temporally and geographically. Therefore, 207 their continuous detailed monitoring is impossible. Continuous detailed monitoring can be 208 replaced by the use of non-pathogenic surrogate organisms, which are sensitive indicators 209 of virulent human pathogens (Carrington, 2001). Organisms used in validation processes are 210 widespread in sludge and easy to maintain for validation tests Escherichia coli have proven 211 to be a suitable indicator by having similar characteristics to vegetative bacteria, for example

212 Salmonella spp., Shigella spp., Listeria spp., and most viruses (Pike et al., 1988; Strauch, 213 1998).

214 Recycling sludge safely in agriculture requires environmentally and ecologically sustainable technologies in efficiently remove hazardous organic pollutants, pharmaceuticals, pathogens, and parasites from sludge. Common methods to stabilize and sanitize sludge in

217 WWTPs are biological anaerobic and aerobic digestion, heat treatment and alkaline stabilization (Arthurson, et al. 2008; Goldfarb et al. 1999). Lime can be used to sanitize and disinfect sludge, and remove different pathogens, particularly bacteria (Urbaniak et al., 2017). Pathogenic microorganisms, which are found in sludge containing fecal and

221 vegetable material, have been listed in the European Commission's Evaluation of Sludge

222 Treatments for Pathogen Reduction - Final Report No: CO 5026/1 (Carrington, 2001).

\section{4. Sludge in agriculture and regulations regarding its use}

\subsection{Sludge on cropland}


Sludge added to cropland has many potentially beneficial impacts due to the improvement of biological, chemical, and physical properties of soils, which may improve plant growth and productivity (Beck et al., 1996; Seleiman et al., 2012, 2013b; Bai et al., 2017; Urbaniak et al., 2017; Rehman et al., 2018; Hudcová et al., 2019). The high organic matter content may improve the functioning of sludge as a soil conditioner by increasing soil water-holding capacity and water infiltration, stabilizing soil temperature fluctuation, serving as a storage of nutrients, and enhancing soil microbial activity (Jarausch-Wehrheim et al., 1999; Epstein, 2003; Samaras et al., 2008; Yan et al., 2009; Seleiman et al., 2013b).

On the other hand, many soil factors, such as $\mathrm{pH}$, organic matter, aeration, cation exchange capacity, water content, temperature, and elemental interactions, can affect the uptake of elements from the soil (Epstein, 2003). Soil pH is considered the main factor affecting the solubility of trace elements. For instance, the solubility of all essential trace elements except molybdenum (Mo) and selenium (Se) is increased at low $\mathrm{pH}$; hence their potential uptake by plants increases. Depending on the environmental conditions, soil organic matter can reduce or increase the plant availability of cationic trace elements, such as $\mathrm{Cd}, \mathrm{Cu}, \mathrm{Ni}$, and $\mathrm{Zn}$, through chelate formation. High cation exchange capacity reduces the mobility of trace elements, such as $\mathrm{Cd}, \mathrm{Cu}, \mathrm{Ni}$, and $\mathrm{Zn}$. Due to the high cation exchange capacity of clay minerals, the binding of trace elements in clay soil is higher than in sandy soil (Epstein, 2003).

Similarly, soil organic matter has, on a mass basis, higher cation exchange capacity than the mineral fraction of soil. The interactions between macronutrients and trace elements can reduce the bioavailability of micronutrients in soil. For example, the interaction between the 
247 phosphate and trace elements can form soluble or insoluble compounds depending on soil $248 \mathrm{pH}$ (Epstein and Chaney, 1978). The less than optimal ratios of plant nutrient content in 249 sludge are generally complemented by adding commercial fertilizers with sludge to cropland 250 to balance the nutrition needed for each species (Yan et al., 2009) (Table 2). 
Table 2

Doses of sludge applications as fertilizer for different plant species grown on cropland

\begin{tabular}{|c|c|c|c|c|}
\hline Sludge type & Dose $\left(\mathrm{t} \mathrm{ha}^{-1}\right)$ & Plant species & Soil type & Authors \\
\hline Sewage sludge & $\begin{array}{l}3.6,7.2,10.8,14.4 \\
18.0\end{array}$ & $\begin{array}{l}\text { Salix discolor Mtihl. } \\
\text { Salix viminalis L. }\end{array}$ & Sandy soil & Labrecque et al. (1995) \\
\hline Sewage sludge compost & $5.9,11.7,29.2,58.5$ & Brassica chinensis L. & Loamy soil & Wong et al. (1996) \\
\hline Municipal sewage sludge & $0,5,7.5,10,15,20$ & Triticum aestivum L. & Coarse loamy sand & Merrington et al. (1997) \\
\hline Digested sewage sludge & $10,20,30,40$ & Phaseolus vulgaris $\mathrm{L}$. & - & Wen et al. (1997) \\
\hline Sewage sludge & 10,100 & Zea mays $\mathrm{L}$. & Acid sandy soil & $\begin{array}{l}\text { Jarausch-Wehrheim et al. } \\
\text { (1999) }\end{array}$ \\
\hline Dried sewage sludge & $10,20,30,40,50$ & Zea mays $\mathrm{L}$. & - & Qasim et al. (2001) \\
\hline Sewage sludge & 60 & Diplotaxis erucoides L. & Clayey and silty soil & $\begin{array}{l}\text { Korboulewsky et al. } \\
\text { (2002) }\end{array}$ \\
\hline $\begin{array}{l}\text { Anaerobically digested and } \\
\text { activated sewage sludge }\end{array}$ & 3.4 & Avena sativa $\mathrm{L}$. & Sandy loam soil & Petersen et al. (2003) \\
\hline Sewage sludge & $7,14,21$ & Sorghum vulgare $\mathrm{L}$. & Sandy clay soils & Akdeniz et al. (2006) \\
\hline $\begin{array}{l}\text { Activated sludge and } \\
\text { facultative stabilization ponds }\end{array}$ & 100 & Sorghum vulgare L. & $\begin{array}{l}\text { Clay loam soil, } \\
\text { sandy loam, loam }\end{array}$ & Mendoza et al. (2006) \\
\hline Sewage sludge & $10,30,50$ & Gossypium hirsutum L. & $\begin{array}{l}\text { Typic Xerochrept } \\
\text { (clay loam) }\end{array}$ & Samaras et al. (2008) \\
\hline Sewage sludge & $0,15,30,60,120$ & $\begin{array}{l}\text { Zoysia japonica, } \\
\text { Poa апnиа }\end{array}$ & Meadow brown soils & Wang et al. (2008) \\
\hline Sewage sludge & $9.8,19.6$ & Zea mays $\mathrm{L}$. & Chernozem & Černý et al. (2012) \\
\hline Digested sludge & 0.9 up to 16.2 & $\begin{array}{l}\text { Zea mays } \mathrm{L} . \\
\text { Cannabis sativa } \mathrm{L} . \\
\text { Brassica napus } \mathrm{L} .\end{array}$ & Vertic Stagnosols & Seleiman et al. (2013a) \\
\hline Sewage sludge & 3 and 9 & Salix viminalis $L$. & Sandy clay soils & Urbaniak et al. (2017) \\
\hline Sewage sludge & $1 \%$ & Triticum aestivum $L$. & Clay loam soils & Rehman et al. (2018) \\
\hline Sewage sludge & $\begin{array}{l}0,25,50,125, \text { and } \\
250\end{array}$ & Sorghum bicolor $L$. & $\begin{array}{l}\text { Halaquepts of } \\
\text { inceptisols }\end{array}$ & Zuo et al. (2019) \\
\hline
\end{tabular}


254 According to Antoline et al. (2005) and Mendoza et al. (2006), sludge application increased

255 the ammonium-N content, cation exchange capacity, and organic carbon content in soil. 256 Unfortunately, sludge application also reduced soil $\mathrm{pH}$ and increased 257 diethylenetriaminepentaacetic acid-extractable heavy metals, i.e., $\mathrm{Cd}, \mathrm{Cu}, \mathrm{Zn}, \mathrm{Pb}$, and $\mathrm{Mn}$ 258 (Antoline et al., 2005; Mendoza et al., 2006). Moreover, the narrow C:N ratio of sludge could 259 also accelerate organic matter decomposition, which could result not only in a loss of organic 260 matter but also a gradual release of heavy metals and metalloids into the soil solution, 261 increasing their availability to plants (Wołejko et al., 2014).

262 When applied as fertilizer, sludge increased the yield of alfalfa (Medicago sativa L.), wheat

263 (Triticum aestivum L.), faba bean (Vicia faba L.), zoysia grass (Zoysia japonica L.), and 264 biomass of maize (Zea mays L.), hemp (Cannabis sativa L.), oilseed rape (Brassica napus 265 L. ssp. oleifera [Moench.] Metzg.), willow (Salix viminalis L.), and sweet sorghum 266 (Sorghum bicolor L.) (Elsokkary and El-Keiy, 1988; Wang et al., 2008; Seleiman et al., 267 2012, 2013a; Urbaniak et al., 2017; Rehmana et al., 2018; Zuo et al., 2019). However, it also 268 increased the heavy metal and metalloid content in the leaves and grains of barley (Hordeum 269 vulgare L.) (Antoline et al., 2005) and sorghum leaves (Sorghum bicolor. L.) (Mendoza et 270 al., 2006), as well as the biomass of maize, hemp, oilseed rape (Seleiman et al., 2012, 2013a, 271 2013b), and sweet sorghum (Zuo et al., 2019), without any visual symptoms of heavy metal 272 toxicity.

273 Apart from improving soil structure and nutrient recycling, agricultural use of sludge also 274 has the potential to save energy compared with synthetic fertilizers. Almost $40 \%$ of the 275 commercial energy used in agriculture is consumed for manufacturing synthetic $\mathrm{N}$ fertilizers 
276 due to the large energy input required for reducing $\mathrm{N}_{2}$ to ammonia in the Haber-Bosch 277 process (Mudahar and Hignett, 1985; Helsel, 1992). The energy needed to produce synthetic 278 fertilizers including the packaging, transportation, and application to the cropland is about $27978 \mathrm{MJ} \mathrm{kg}^{-1} \mathrm{~N}, 17 \mathrm{MJ} \mathrm{kg}^{-1} \mathrm{P}$, and $14 \mathrm{MJ} \mathrm{kg}^{-1} \mathrm{~K}$ (Helsel, 1992; Elsayed and Mortimer, 2001; 280 Mikkola and Ahokas, 2009). Production of N fertilizers increased from 11.6 to $122.7 \mathrm{Mt}$ and 281 synthetic P fertilizers from 10.0 to 50.8 Mt during the period 1961-2016 (IFASTAT, 2016; 282 FAOSTAT, 2012, 2019). During the period 2002-2016, the agricultural use of $\mathrm{N}$ fertilizers 283 increased from 82.5 to 110.2 Mt and the use of P fertilizers from 34.6 to 48.6 Mt (Figure 3) 284 (FAOSTAT, 2019). 


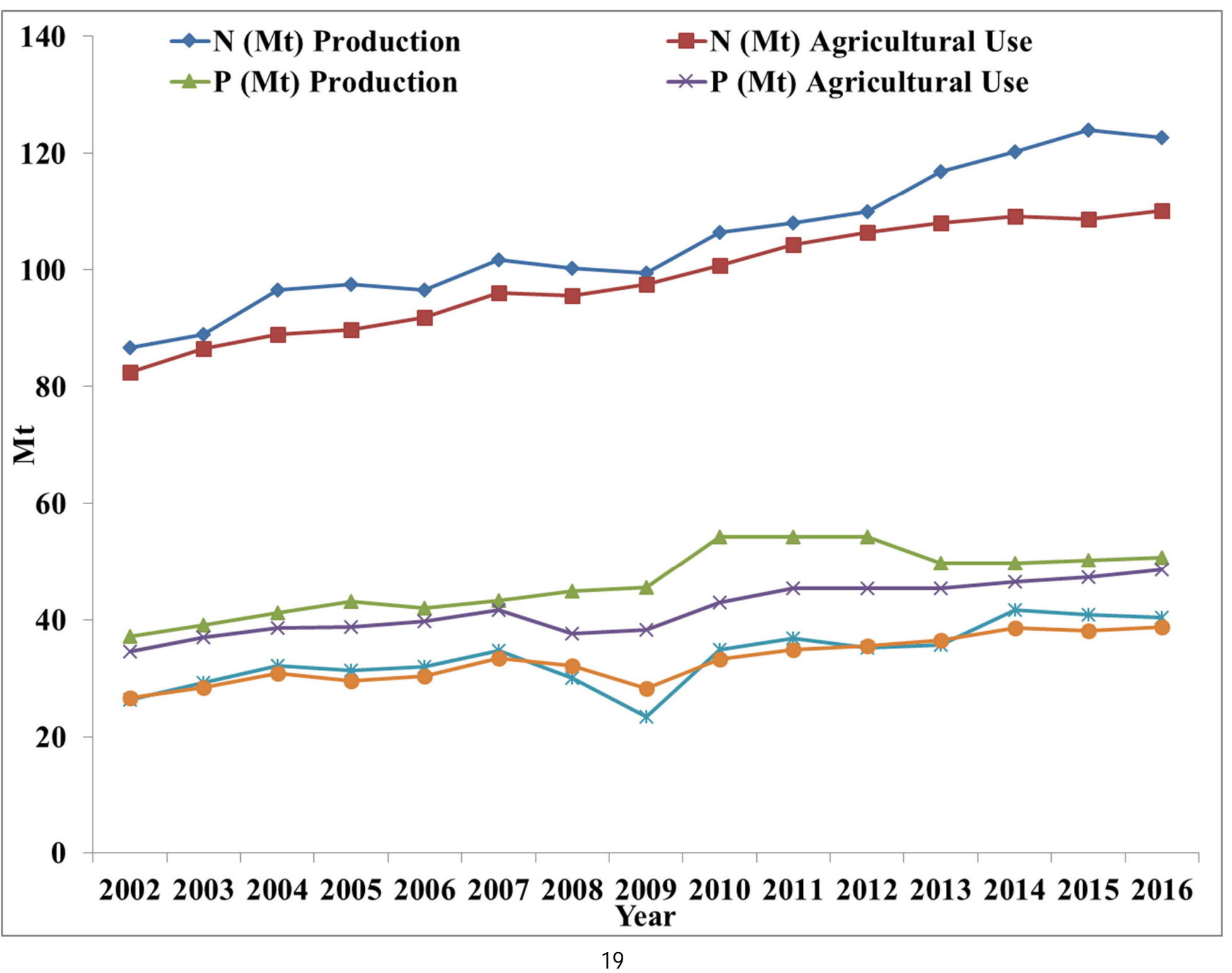


Figure 3

287 World production and agricultural use of nitrogen $(\mathrm{N})$, phosphorus $(\mathrm{P})$, and potassium $(\mathrm{K})$ fertilizers during 2002-2016

288 (FAOSTAT, 2019). 


\subsection{Main regulations related to use of sludge on cropland}

Sludge can contain, depending on the source and processing technique in WWTPs, a quantitatively and qualitatively variable range of harmful compounds, pathogens, and pharmaceuticals (Carrington, 2001; Clark and Smith 2011; Seleiman et al., 2013a; AlGheethi et al., 2018; Hudcová et al., 2019). Therefore, its use on land is usually regulated. The amount of heavy metals in sludge as well as in soil to which sludge is applied is strictly regulated in the EU (Table 3). Council Directive 86/278/EEC of 12 June 1986 aimed to protect the environment and prevent the harmful effects of adding sludge to cropland to plants, animals, and humans (European Commission, 1986). The directive restricts: 1) contamination of the soil by heavy metals and metalloids by limiting the contents of heavy metals and metalloids in the soil to which sludge is applied, 2) the content of heavy metals and metalloids in sludge, as well as 3) the amounts of heavy metals that can be annually added to the soil (Table 3) and the maximum number of pathogens in sludge (European Commission, 1986). Some EU countries have more restrictive requirements compared with Directive 86/278/EEC and have approved the limits for heavy metal concentrations, synthetic organic compounds, and microbial contamination (Hudcová et al., 2019). For example, in the Netherlands the limits of $\mathrm{Cd}, \mathrm{Cu}, \mathrm{Ni}, \mathrm{Pb}$ and $\mathrm{Zn}$ concentrations in sludge should not exceed 1.2, 75, 30, 100, and $300 \mathrm{mg} \mathrm{kg}^{-1}$, respectively (EUROSTAT, 2018; Hudcová et al., 2019).

In the EU, specific requirements for organic compounds in sludge are not included in Directive 86/278/EEC, but to reduce potential health risks several national regulations include limitations concerning the allowable amounts of organic compounds in the sludge 
311 applied to cropland. For example, the limits of PAHs and PCBs were 6.5 and $1.0 \mathrm{mg} \mathrm{kg}^{-1}$

312 DM sludge in Bulgaria, respectively, while the limits of DEHP, LASs, NPEs, and PAHs

313 were 50, 300, 10, and $3 \mathrm{mg} \mathrm{kg}^{-1} \mathrm{DM}$ sludge in Denmark, respectively. In addition, the limits

314 of adsorbed organic halogen compounds (AOX) and PCBs were 500 and $0.2 \mathrm{mg} \mathrm{kg}^{-1} \mathrm{DM}$

315 sludge in Germany, respectively (European Commission, 2000; Hudcová et al., 2019).

\section{Table 3}

317 European Union limits for heavy metals in sludge and soil to which sludge is applied 318 (European Commission, 1986, 2001, 2002)

\begin{tabular}{|c|c|c|c|c|c|c|}
\hline & $\mathrm{Cd}$ & $\mathrm{Ni}$ & $\mathrm{Cu}$ & $\mathrm{Cr}$ & $\mathrm{Pb}$ & $\mathrm{Zn}$ \\
\hline Soil treated with sludge $\left(\mathrm{mg} \mathrm{kg}^{-1} \mathrm{DM}\right)$ & 3 & 75 & 140 & 150 & 300 & 300 \\
\hline \multicolumn{7}{|l|}{ Previous regulations(before 2015) } \\
\hline Heavy metals in sludge ( $\left.\mathrm{mg} \mathrm{kg}^{-1} \mathrm{DM}\right)$ & 40 & 400 & 1750 & 1000 & 1200 & 4000 \\
\hline $\begin{array}{l}\text { Maximum load of heavy metals to } \\
\text { agricultural soil }\left(\mathrm{g} \mathrm{ha}^{-1} \text { year }^{-1}\right)\end{array}$ & 150 & 3000 & 12000 & 3000 & 1500 & 30000 \\
\hline \multicolumn{7}{|l|}{ Current regulations from 2015} \\
\hline Heavy metals in sludge ( $\left.\mathrm{mg} \mathrm{kg}^{-1} \mathrm{DM}\right)$ & 5 & 200 & 800 & 800 & 1500 & 2000 \\
\hline $\begin{array}{l}\text { Maximum load of heavy metals to } \\
\text { agricultural soil }\left(\mathrm{g} \mathrm{ha}^{-1} \text { year }^{-1}\right)\end{array}$ & 15 & 600 & 2400 & 2400 & 1500 & 6000 \\
\hline \multicolumn{7}{|l|}{ Proposed regulations 2025} \\
\hline Heavy metals in sludge ( $\left.\mathrm{mg} \mathrm{kg}^{-1} \mathrm{DM}\right)$ & 2 & 100 & 600 & 600 & 200 & 1500 \\
\hline $\begin{array}{l}\text { Maximum load of heavy metals to } \\
\text { agricultural soil }\left(\mathrm{g} \mathrm{ha}^{-1} \text { year }^{-1}\right)\end{array}$ & 6 & 300 & 1800 & 1800 & 600 & 4500 \\
\hline
\end{tabular}

DM, dry matter

In the USA, the Environmental Protection Agency's regulation 40 CFR Part 503 Standards for the Use or Disposal of Sewage Sludge (U.S. Federal Register, 1993) defines two sludge classes: Class A and Class B. Class A sludge has undergone composting, heat drying, and high-temperature aerobic digestion, which reduces pathogenic bacteria, enteric viruses, and viable helminths' ova to below detectable levels. Class A sludge can be used as a soil 
amendment without imposing site and harvesting restrictions. Class B sludge may still contain some pathogens, and thus its application is restricted for the harvestable crops, animal grazing, and public access for a period of time after application (U.S. Federal Register, 1993).

Sludge application is also limited in many European countries either as a maximum amount $\mathrm{ha}^{-1}$ year $^{-1}$ or by P-based agronomic rates. In the USA, a N-based application rate is used and no specific limitations for organic contaminants exist (Harrison et al., 2006).

\section{Risk of contamination of food chain and the environment}

Potential adverse effects of toxic inorganic and organic compounds on the environment and living organisms through the food chain follow the application of sludge to cropland (Epstein, 2003; Schowanek et al., 2004; Bai et al., 2017). Sludge can pose a risk to the surface water and groundwater (Rlöpffer, 1996; Grobelak et al., 2017), the environment, and thus the food chain (Duarte-Davidson and Jones, 1996). Pathogens in sludge can pose risks to human health if transferred to food crops grown on sludge-treated soils (Yan et al., 2009; Urbaniak et al., 2017; Hudcová et al., 2019).

Even though sludge is a valuable source of nutrients, for example excessive $\mathrm{P}$ accumulation in soil as a source of pollution for surface water and groundwater is of concern (Grobelak et al., 2017). This can be caused by the non-optimal ratios of plant nutrients in sludge. Sludge application at recommended rates based on the content of available soil P might result in an accumulation of $\mathrm{P}$ in soil, which can increase the risk of eutrophication and an adverse impact on water bodies through surface runoff, subsurface drainage water, and eroded soil. To avoid leaching of $\mathrm{P}$ into the environment, wastewater treatment facilities have been 

WWTPs, where Fe, aluminum (Al), or Ca are used during pretreatment to reduce the soluble $\mathrm{P}$ (to meet effluent limits), also has lower $\mathrm{P}$ available to plants (i.e., less than $25 \%$ of that in triple superphosphate). Phosphate is strongly adsorbed to the surfaces of Fe and Al hydrous oxides and calcium carbonate (Bastin et al., 1999). In addition, heat-dried sludge has low $\mathrm{P}$ availability.

Heavy metals and metalloids are non-biodegradable and can be taken up by plant roots and stored in different plant tissues (Wagner, 1993; McLaughlin et al., 1999). The possibility of their accumulation in human tissues and biomagnification via the food chain can cause risks to human health and the environment (Krogmann et al., 1999). The mobility of heavy metals, their bioavailability, and their link to ecotoxicity are based on their specific chemical forms and the mechanisms of binding (Fuentes et al., 2004).

Fuentes et al. (2004) investigated four different products of sludge deriving from different wastewater plant treatments (i.e., aerobic, anaerobic, unstabilized, and sludge from a waste stabilization pond) to compare the influence of the stabilization method on the distribution of heavy metals. Based on that, anaerobic sludge should not be applied to cropland due to its high $\mathrm{Cr}$ content. Sludge from a waste stabilization pond, which had a higher level of mineralization and stabilization than the other products of sludge, had a lower heavy metal availability index. This could be due to a correlation between the mobile oxidizable and residual fractions. In contrast, the unstabilized sludge had the highest heavy metal accumulation in the most easily assimilable fractions (bioavailable, exchangeable, and reducible) (Fuentes et al., 2004). 
369 A high content of persistent and bioaccumulative organic contaminants in sludge is a concern 370 when sludge is used on cropland and in landfills, which may result in the spread of organic

371 pollutants into the environment and food chain. Many organic pollutants include a number 372 of congeners with different chemical quality and toxicities (Hudcová et al., 2019). The 373 concentrations of many of those "traditional" organic contaminants in sludge is regulated by 374 source control, but there exist still vast number of emerging potential compounds whose 375 toxicity and behavior in soil and water bodies have not been analyzed yet (Eriksson et al. 376 2008).

377 Temperature and time affect the degradation rate of LAS and NPE compounds in soil, which 378 must be considered when timing sludge storage and application to soil. For example, the 379 half-life of LAS at $22{ }^{\circ} \mathrm{C}$ was 7 days in comparison with 14 days at $13{ }^{\circ} \mathrm{C}$ (Gonzaléz et al., 380 2010), and it took 56 days for NPE and 23 days for LAS to lose toxicity in the soil (Garrido381 Perez et al., 2008). Thus, LAS and NPE compounds can be loaded into soil via sludge and 382 transferred into surface water and groundwater. In the environment, NPEs degrade to 383 nonylphenol (NP) which is more persistent and toxic especially in aquatic environment (U.S.

384 Environmental Protection Agency, 2010).

385 These organic xenobiotics can also inhibit processes like degradation of organic matter and 386 mineralization (Kümmerer, 2009; Eriksson et al., 2008). If it accumulates in the food chain, 387 NPE as a pseudo-estrogen will disrupt the animal and human endocrine system.

Clarke and Smith (2011) ranked selected emerging organic compounds using an assessment matrix approach with five properties: 1) environmental persistence (> 6 months), 2) human 
toxicity, 3) bioaccumulation, 4) ecotoxicity, and 5) number and quality of international studies of the contaminant. On the basis of the results, the organic compounds were organized in decreasing priority as follows: perfluorinated chemicals (PFCs) > polychlorinated alkanes (PCAs) and polychlorinated naphthalenes (PCNs) > organotins, polybrominated diphenyl ethers, triclosan and triclocarban $>$ benzothiazoles $>$ antibiotics and pharmaceuticals > synthetic musks > bisphenol A and phthalate acid esters and quaternary ammonium compounds > steroids, and polydimethylsiloxanes.

In hazard identification analysis of including 192 organic compounds commonly found in sludge, $51,6 \%$ were classified as hazardous, $12,5 \%$ as non-hazardous and $32,8 \%$ of the compounds could not be classified due to the lack of basic data, such as biodegradation, short-term and chronic toxicity for the aquatic and soil organisms (Eriksson et al., 2005). Short-chain perfluorochemicals (PFCs), perfluorooctanoic acid (PFOA), perfluorooctane sulfonates (PFOS), and polychlorinated alkanes (PCAs) have caused concern. All these substances have been found in human blood (Olsen et al., 2003), human milk (Thomas et al., 2006), and the environment (Campbell and McConnell, 1980; Giesy and Kannan, 2001). PCAs are persistent and bioaccumulative and their mean concentration of sludge collected from WWTPs in UK was much higher, $1800 \mathrm{mg} \mathrm{kg}^{-1} \mathrm{DM}$ in comparison to other persistent organic pollutants (Stevens et al 2003). Short-chain PCAs and PFOAs are identified as priority hazardous substances by European Water Framework directive and placed restrictions on marketing and use (REACH Annex XVII).

Uptake of organic compounds by plants depends on the lipophilicity and water solubility of the substance, the ambient temperature, as well as the concentration of organic compounds 
413 in the soil and plants (Simonich and Hites, 1995). Organic compounds are taken up from a

414 soil solution by roots and translocated into the leaves. Some of these compounds can be 415 metabolized during the uptake and some intermediates can be translocated from the roots to 416 other plant parts, while others can remain in the plant roots. Volatile organic contaminants 417 can enter foliage through the wax-containing cuticle, which can bind and store lipophilic 418 organic compounds, as well as through the stomata (Duarte-Davidson and Jones, 1996).

419 Maize uptake of PFCs from nutrient medium was dependent on chain length of substances. 420 For instance, short-chain substances were taken up more actively than long-chain substances, 421 and translocated to shoot. Whereas higher concentration of long-chain substances, for 422 example PFOA and PFOS, accumulated in roots (Krippner et al. 2014). Wheat and 423 earthworms (Eisenia fetida L.) take up PFOS precursor perfluorooctane sulfonamide, which 424 is transformed to PFOS in both organisms and other derivatives in wheat (Zhao et al. 2018). 425 Organic compounds in soil treated with sludge can translocate and accumulate in grazing 426 livestock, depending on some factors such as livestock species, type of sludge applied to the 427 soil, and growing season. For example, PAHs could adhere to plant root surfaces and the 428 lighter molecular weight compounds might volatilize from polluted soil into the foliage. 429 Grazing livestock can ingest the organic compounds in three different ways: (a) grazing, (b) 430 adhering to soil and/or sludge with harvested forage, and (c) ingestion of the soil-sludge 431 mixture. For instance, up to $2 \%$ of a sheep's diet is soil (Duarte-Davidson and Jones, 1996). 432 Nonpolar and persistent organic compounds can be stored and accumulated in fat tissues and 433 milk if not metabolized (Wild and Jones, 1992). Other organic compounds such as PCDD/Fs, 434 PCBs, and hexachlorobenzene are not metabolized (Geyer et al., 1987). In fact, the potential 
436 get PCDD/Fs from animal fat - mostly dairy products and beef (Fürst et al., 1990; Beck et 437 al., 1992).

438 The livestock industry, manure, as well as industrial and hospital wastewater can contain 439 zoonotic and non-zoonotic pathogens and antimicrobial-resistant bacteria. Mesophilic 440 treatment or even short thermophilic treatment is not always enough to eliminate pathogens 441 from sludge. The samples from raw sludge (67\%) and digested sludge (55\%) were positive 442 for different Salmonella spp. serotypes as well as Campylobacter (2\%) and Listeria (4\%) 443 after a 9-day thermophilic and 28-day mesophilic treatment (Sahlström et al., 2004). In 444 general, an over 10-day thermophilic treatment is required for appropriate sanitation of 445 Escherichia coli and Salmonella spp. in sludge. However, spores of C. perfringens were not 446 destroyed even in a 15-day thermophilic treatment (Coelho et al., 2011; Lloret et al., 2013). 447 The safe recycling of sludge in agriculture requires that contaminants and pollutants 448 accumulating from wastewaters into sludge are identified and environmental risk 449 assessments made to determine the limits for these contaminants in sludge intended for 450 agricultural purposes (Andersen, 2001). 


\section{Conclusions}

Even though sludge seems to be a good source of nutrients and improves the level of nutrient recycling, the application of sludge to cropland should not adversely affect groundwater or the food chain. Before sludge recycling in agriculture can be widely accepted, more information about possible interactions between inorganic and organic compounds and their intermediate reaction products, their accumulation and persistence in the environment, is required. To date, few investigations have been done on the leaching of organic pollutants when sludge is applied to soil. Further investigations are needed on the residual organic chemicals remaining in the soil or taken up by plants when sludge is applied to cropland, as such work is important for assessing the risks posed to the environment and food chain.

Conflicts of Interest: The authors declare no conflict of interest.

\section{References}

Addorisio, V., Sannino, F., Mateo, C., Guisan, J.M., 2013. Oxidation of phenyl compounds using strongly stable immobilized-stabilized laccase from Trametes versicolor. Process Biochem. 48, 1174-1180.

Ahel, M., Giger, W., Koch, M., 1994. Behaviour of alkylphenol polyethoxylate surfactants in the aquatic environment. Occurrence and transformation in sewage treatment. Water Res. 28, 1131-1142.

Akdeniz, H., Yilmaz, I., Bozkurt, M.A., Keskin, B., 2006. The effects of sewage sludge and nitrogen applications on grain sorghum grown (Sorghum vulgare L.) in Van-Turkey. Pol. J. Environ. Stud. 15, 19-26. 
Al-Gheethi, A.A., Efaq, A.N., Bala, J.D., Norli, I., Abdel Monem, M.O., Kadir M.O. Ab., 2018. Removal of pathogenic bacteria from sewage treated effluent and biosolids for agricultural purposes. Appl. Water Sci. 8, 74.

Andersen, R., 2001. Disposal and Recycling Routes for Sewage Sludge. Part 3-Scientific and Technical Report. Report for the European Commission. Available from: http://ec.europa.eu/environment/archives/waste/sludge/pdf/sludge_disposal3.pdf. [Accessed 11.05.2019].

Andreoli, C.V., Pegorini, E.S., Fernandes, F., Santos, H.F., 2007. Land application of sewage sludge. In: Von Sperling, M., Andreoli, C.V., Fernandes, F., (Eds.), Sludge Treatment and Disposal. IWA Publishing, London, pp. 162-206.

Antoline, C.M., Inmaculada, P., Carlos, G., Alfredo, P., Manuel, S.D., 2005. Growth, yield and solute content of barley in soils treated with sewage sludge under semiarid Mediterranean conditions. Field Crop Res. 94, 224-237.

Arthurson, V. 2008., Proper sanitization of sewage sludge: a Critical issue for a sustainable society. Appl. Environ. Microbiol. 74, 5267-5275.

Bai, Y., Zang, C., Gu, M., Gu, C., Shao, H., Guan, Y., Wang, X., Zhou, X., Shan, Y., Feng, F., 2017. Sewage sludge as an initial fertility driver for rapid improvement of mudflat salt-soils. Sci. Total Environ. 578, 47-55.

Bastin, O., Janssens, F., Dufey, J., Peeters, A., 1999. Phosphorus removal by a synthetic iron oxide-gypsum compound. Ecol. Eng. 12, 339-351. 
Beck, A.J., Johnson, D.L., Jones, K.C., 1996. The form and bioavailability of non-ionic organic chemicals in sewage sludge-amended agricultural soils. Sci. Total Environ. $185,125-149$.

Beck, H., Dro, D.A., Mathar, W., 1992. PCDDs, PCDFs and related contaminants in the German food supply. Chemosphere 25, 1539-1550.

Berktay, A., Nas, B., 2008. Biogas production and utilization potential of wastewater treatment sludge. Energy Sources Part A 30, 179-188.

Bianchini, A., Bonfiglioli, L., Pellegrini, M., Saccani, C., 2016. Sewage sludge management in Europe: a critical analysis of data quality. Int. J. Environ. Waste Manag. 18, 226-238.

Bozkurt, M.A., Akdeniz, H., Keskin, B.Y., Ibrahim, H., 2006. Possibilities of using sewage sludge as nitrogen fertilizer for maize. Acta Agric. Scand., Sec. B - Soil Plant Sci. 56, $143-149$.

Brunner, P.H., Capri, S., Marcomini, A., Giger, W., 1988. Occurrence and behaviour of linear alkylbenzenesulphonates, nonylphenol, nonylphenol mono- and nonylphenol diethoxylates in sewage and sewage sludge treatment. Water Res. 22, 1465-1472.

Campbell, I., McConnell, G., 1980. Chlorinated paraffins and the environment. 1. Environmental occurrence. Environ. Sci. Technol. 14, 1209-1214.

Carrington, E.G., 2001. Evaluation Sludge Treatments for Pathogen Reduction - Final $\begin{array}{llll}\text { Report No: } & \text { 5026/1. } & \text { Available }\end{array}$ http://ec.europa.eu/environment/archives/waste/sludge/pdf/sludge_eval.pdf [Accessed 11.05.2019]. 
Catapane, M., Nicolucci, C., Menale, C., Mita, L., Rossi, S., Mitaa, D.G., Diano, N., 2013. Enzymatic removal of estrogenic activity of nonylphenol and octylphenol aqueous solutions by immobilized laccase from Trametes versicolor. J. Hazard. Mater. 248 \& $249,337-346$.

Černý, J., Balík, J., Kulhánek, M., Vašák, F., Peklová, L., Sedlář, O., 2012. The effect of mineral $\mathrm{N}$ fertiliser and sewage sludge on yield and nitrogen efficiency of silage maize. Plant, Soil Environ. 58, 76-83.

Clarke, B.O., Smith, S.R., 2011. Review of 'emerging' organic contaminants in biosolids and assessment of international research priorities for the agricultural use of biosolids. Environ. Int. 37, 226-247.

Coelho, N.M .G., Droste, R.L., Kennedy, K.J., 2011. Evaluation of continuous mesophilic, thermophilic and temperature phased anaerobic digestion of microwaved activated sludge. Water Res. 45 , $2822-2834$.

Cruz-Morató, C., Ferrando-Climent, L, Rodriguez-Mozaz, S., Barceló, D., Marco-Urrea, E., Vicent, T., Sarrà, M., 2013. Degradation of pharmaceuticals in non-sterile urban wastewater by Trametes versicolor in a fluidized bed bioreactor. Water Res. 47, 52005210.

Deng,Y., Zhao, R., 2015. Advanced Oxidation Processes (AOPs) in Wastewater Treatment. Curr. Pollution Rep. 1, 167-176.

Du, W., Jiang, J., Gong, C., 2012. Primary research on agricultural effect of sludge - impact of sludge application on crop seeds germination and seedling growth. Proced. Environ. Sci. 16, 340-345. 
Duarte-Davidson, R., Jones, K.C., 1996. Screening the environmental fate of organic contaminants in sewage sludge applied to agricultural soils: II. The potential for transfers to plants and grazing animals. Sci. Total Environ. 185, 59-70.

Elsayed, M., Mortimer, N., 2001. Carbon and Energy Modelling of Biomass Systems: Conversion Plant and Data Updates. Available from: http://webarchive.nationalarchives.gov.uk/+/http://www.berr.gov.uk/files/file14926.p df. [Accessed 01.05.2019].

Elsokkary, I.H., El-Keiy, O.M., 1988. Effect of sewage sludge application on the growth and heavy metals content of five plant crops grown on calcareous soil. Proceedings of the $3^{\text {rd }}$ International Conference on Environment Contamination, September 26-29, 1988, Venice, pp. 170-173.

Epstein, E., 2003. Land Application of Sewage Sludge and Biosolids, CRC Press, New York.

Epstein, E., Chaney, R.L., 1978. Land disposal of toxic substances and water - related problems. J. Water Pollut. Control Fed. 50, 2037-2042.

Eriksson, E., Baun, A., Mikkelsen, P.S., Ledin, A., 2005. Chemical hazard identification and assessment tool for evaluation of stormwater priority pollutants. Water Sci. Technol.

Eriksson, E., Christensen, N., Schmidt, E.J., Ledin, A., 2008. Potential priority pollutants in sewage sludge. Desalination 226, 371-388.

European Chemicals Agency, 2018. Available at: https://echa.europa.eu/ [Accessed 11.05.2019]. 
558

559

560

561

562

563

564

565

566

567

568

569

570

571

572

573

574

575

576

577

578

579

European Commission, 1986. Protection of the Environment, and in Particular of the Soil, When Sewage Sludge is Used in Agriculture. Official Journal of the European Communities, L181 (86/278/EEC), 6-12. Available from: https://eurlex.europa.eu/legal-content/EN/TXT/?uri=celex\%3A31986L0278

[Accessed 11.05.2019].

European Commission, 2000. Working Document on Sludge. 3rd Draft. Brussels, 27 April 2000, ENV.E.3/LM.

European Commission, 2001. Disposal and Recycling Routes for Sewage Sludge. Part 2Regulatory Report. Available from: http://ec.europa.eu/environment/archives/waste/sludge/pdf/sludge_disposal2.pdf [Accessed 10.05.2019].

European Commission, 2002. Disposal and Recycling Routes for Sewage Sludge. Part 4Economic Report. Available from: http://ec.europa.eu/environment/archives/waste/sludge/pdf/sludge_disposal4.pdf [Accessed 10.05.2019].

EUROSTAT, 2018. Sewage Sludge Production and Disposal. Available from: https://ec.europa.eu/eurostat/web/products-datasets/product?code=env_ww_spd. [Accessed 01.05.2019]

FAOSTAT, 2012. Fertilizers. FAO Statistical Databases \& Data-sets. Available from: http://faostat.fao.org/site/291/default.aspx. [Accessed 01.05.2019].

FAOSTAT, 2019. Fertilizers. FAO Statistical Databases \& Data-sets. Available from: http://www.fao.org/faostat/en/\#data/RFB. [Accessed 01.05.2019]. 
Fijalkowski, K., Rorat, A., Grobelak, A., Kacprzak, M.J., 2017. The presence of contamination in sewage sludge - the current situation. J. Environ. Manag. 203, 11261136.

Franke-Whittle, I.H., Insam, H., 2013. Treatment alternatives of slaughterhouse wastes, and their effect on the inactivation of different pathogens: A review. Crit. Rev. Microbiol. 39, 139-151.

Fuentes, A., Llorens, M., Saez, J.M., Soler, A., Aguilar, M., Ortuno, J.F., Meseguer, V.F., 2004. Phytotoxicity and heavy metals speciation of stabilised sewage sludges. J. Hazard. Mater. 108, 161-169.

Fürst, P., Fürst, C., Groebel, W., 1990. Levels of PCDDs and PCDFs in food-stuffs from the Federal Republic of Germany. Chemosphere 20, 787-792.

Fytili, D., Zabanioto, A., 2008. Utilization of sewage sludge in EU application of old and new methods-A review. Renew. Sust. Energy Rev. 12, 116-140.

Gardiner, D.T.,, Miller, R.W., Badamchian, N., Azzari, A.Z., Sisson, D.R., 1995. Effects of repeated sewage sludge applications on plant accumulation of heavy metals. Agric. Ecosyst. Environ. 55, 1-6.

Garrido-Perez, M.C., Perales-VargasMachuca, J.A., Nebot-Sanz, E., Sales-Márquez, D., 2008. Effect of the test media and toxicity of LAS on the growth of Isochrysis galbana. Ecotoxicology 17, 738-746.

Geyer, H., Scheunert, I., Korte, F., 1987. Correlation between the bioconcentration potential of organic environmental chemicals in humans and their n-octanol/ water partition coefficients. Chemosphere 16, 239-252. 
602

603

604

605

606

607

608

609

610

611

612

613

614

615

616

617

618

619

620

621

622

Giesy, J.P., Kannan, K., 2001. Global distribution of perfluorooctane sulfonate in wildlife. Environ. Sci. Technol. 35, 1339-1342.

Gilbert, P., Thornley, P., Riche, A., 2011. The influence of organic and inorganic fertiliser application rates on UK biomass crop sustainability. Biomass Bioenergy 35, 1170 1181.

Goldfarb, W., Krogmann U., Hopkins, C., 1999. Unsafe sewage sludge or beneficial biosolids? Liability, planning, and management issues regarding the land application of sewage treatment residuals. Boston Coll. Environ. Affairs Law Rev. 26, 687-768.

Gonzaléz, M.M., Martin, J., Santos, J.L., Aparicio, I., Alonso, E., 2010. Occurrence and risk assessment of nonylphenol and nonylphenol ethoxylates in sewage sludge from different conventional treatment processes. Sci. Total Environ. 408, 563-570.

Grobelak, A., Placek, A., Grosser, A., Singh, B., Almås, Å., Napora, A., Kacprzak, M., 2017. Effects of single sewage sludge application on soil phytoremediation. J. Clean. Prod. $155,189-197$.

Gu, C., Bai, B., Tao, T., Chen, G., Shan, Y., 2013. Effect of sewage sludge amendment on heavy metal uptake and yield of ryegrass seedling in a Mudflat soil. J. Environ. Qual. $42,421-428$.

Harrison, E.Z., Oakes, S.R., Hysell, M., Hay, A., 2006. Organic chemicals in sewage sludges. Sci. Total Environ. 367, 481-497.

Helsel, Z.R., 1992. Energy and alternatives for fertilizer and pesticide use. In: Fluck, R.C. (Ed.), Energy in Farm Production. Elsevier Publisher, Vol. 6, pp. 177-201. 
Hudcová, H., Vymazal, J., Rozkošný, M., 2019. Present restrictions of sewage sludge application in agriculture within the European Union. Soil Water Res. 14, 104-120.

IC Consultants, 2001. Pollutants in Urban Wastewater and Sewage Sludge. Final Report for Directorate-General Environment, European Commission. Available from: http://ec.europa.eu/environment/archives/waste/sludge/pdf/sludge_pollutants_xsum.p df, $11 \mathrm{p}$ [Accessed 10.05.2019].

IFASTAT., 2016. Statistics: Fertilizer Industry Association. Available from: https://www.ifastat.org/ [Accessed 10.05.2019].

Jarausch-Wehrheim, B., Mocquot, B., Mench, M., 1999. Absorption and translocation of sludge-borne zinc in field-grown maize (Zea mays L.). Europ. J. Agron. 11, 23-33.

Jelic, A., Gros, M., Ginebreda, A., Cespedes-Sa'nchez, R., Ventura, F., Petrovic, M. \& Barcelo, D. 2011. Occurrence, partition and removal of pharmaceuticals in sewage water and sludge during wastewater treatment. Water Res. 45, 1165-1176.

Kidd, P.S., Domínguez-Rodríguez, M.J., Díez, J., Monterroso, C., 2007. Bioavailability and plant accumulation of heavy metals and phosphorus in agricultural soils amended by long-term application of sewage sludge. Chemosphere 66, 1458-1467.

Korboulewsky, N., Bonin, G., Massiani, C., 2002. Biological and ecophysiological reactions of white wall rocket (Diplotaxis erucoides L.) grown on sewage sludge compost. Environ. Pollut. 117, 365-370.

Krippner, J., Brunn, H., Falk, S., Georgii, S., Stahl,T., 2014. Effects of chain length and pH on the uptake and distribution of perfluoroalkyl substances in maize (Zea mays L.). Chemosphere 94, 85-90. 
Krogmann, U., Boyles, L.S., Bamka, W.J., Chaiprapat, S., Martel, C.J., 1999. Biosolids and sludge management. Water Environ. Res. 71, 692-714.

647 Kümmerer K. 2009. Antibiotics in the aquatic environment - Review- Part 1. Chemosphere $75,417-434$.

Labrecque, M., Teodorescu, T.I., Daigle, S., 1995. Effect of wastewater sludge on growth and heavy metal bioaccumulation of two Salix species. Plant Soil 171, 303-316.

Li, X., Ke, Z., Dong, J., 2011. PCDDs and PCDFs in sewage sludge from two wastewater treatment plants in Beijing, China. Chemosphere 82, 635-638.

Lillenberg, M., Yurchenko, S., Kipper, K., Herodes, K., Pihl, V., Lõhmus, R., Ivask, M., Kuu, A., Kutti, S., Litvin, S. V., Nei, L., 2010. Presence of fluoroquinolones and sulfonamides in urban sewage sludge and their degradation as a result of composting. Int. J. Environ. Sci. Tech. 7, 307-312.

Lloret, E., Pastor, L., Pradas, P., Pascual, J.A., 2013. Semi full-scale thermophilic anaerobic digestion (TAnD) for advanced treatment of sewage sludge: Stabilization process and pathogen reduction. Chem. Eng. J. 232, 42-50.

Lovingood, T., Trynosky, J., Drzewiecki, J., Beeson, B., Milligan, P., 2018. EPA Unable to Assess the Impact of Hundreds of Unregulated Pollutants in Land-applied Biosolids on Human Health and the Environment. Report No. 19-P-0002, Available from: https://www.epa.gov/sites/production/files/201811/documents/ epaoig 20181115-19-p-0002.pdf [Accessed 18.05.2019]

Łuczkiewicz, A., 2006. Soil and groundwater contamination as a result of sewage sludge 666 land application. Pol. J. Environ. Stud. 15, 869-876. 
Martín, J., Camacho-Muñoz, D., Santos, J.L., Aparicio, I., Alonso, E., 2012. Occurrence of pharmaceutical compounds in wastewater and sludge from wastewater treatment plants: removal and ecotoxicological impact of wastewater discharges and sludge disposal. J. Hazard. Mater. 239-340, 40-47

McLaughlin, M.J., Parker, D.R., Clarke, J.M., 1999. Metals and micronutrients - food safety issues. Field Crops Res. 60, 143-163.

Mendoza, J., Tatiana, G., Gabriela, C., Nilsa, S.M., 2006. Metal availabiltiy and uptake by sorghum plants grown in soils amended with sludge from different treatments. Chemosphere 65, 2304-2312.

Merrington, G., Winder, L., Green, I., 1997. The bioavailability of $\mathrm{Cd}$ and $\mathrm{Zn}$ from soils amended with sewage sludge to winter wheat and subsequently to the grain aphid Sitobion avenae. Sci. Total Environ. 205, 245-254.

Mikkola, H.J., Ahokas, J., 2009. Energy ratios in Finnish agricultural production. Agric. Food Sci. 18, 332-346.

Mitchell, S. M., Bary, A., Ullman, J. L., Teel, A. L. 2015. Antibiotic Degradation During Thermophilic Composting. Water Air Soil Pollut. 226:13.

Mooso, G., Tindall, T.A., Hettiarachchi, G., 2013. Phosphorus use efficiency in crop production. In: Western Nutrient Management Conference. Reno, March 7-8, 2013, Vol. 10, 87-91.

Mudahar, M.R., Hignett, T.P., 1985. Energy efficiency in nitrogen fertilizer production. Energy Agric. 4, 159-177. 
688

689

690

691

692

693

694

695

696

697

698

699

700

701

702

703

704

705

706

707

708

Olsen, G.W., Church, T.R., Miller, J.P., Burris, J.M., Hansen, K.J., Lundberg, J.K., Armitage, J.B., Herron, R.M., Medhdizadehkashi, Z., Nobiletti, J.B., O’Neil, E.M., Mandel, J.H., Zobel, L.R., 2003. Perfluorooctanesulfonate and other fluorochemicals in the serum of American Red Cross adult blood donors. Environ. Health Perspect. $111,1892-1901$.

Pakou, C., Kornaros, M., Stamatelatou, K., Lyberatos, G., 2009. On the fate of LAS, NPEOs and DEHP in municipal sewage sludge during composting. Bioresour. Technol. 100, $1634-1642$

Pepper, I.L., Brooks, J.P., Gerba, C.P., 2006. Pathogens in biosolids. Adv. Agron. 90, 1-41. Petersen, S.O., Petersen, J., Rubæk, G.H., 2003. Dynamics and plant uptake of nitrogen and phosphorus in soil amended with sewage sludge. Appl. Soil Ecol. 24, 187-195.

Pike, E.B., Carrington, E.G., Harman, S.A., 1988. Destruction of salmonellas, enteroviruses and ova of parasites in wastewater sludge by pasteurisation and anaerobic digestion. Water Sci. Technol. 20, 337-343.

Qasim, M., Himayatullah, J.N., Subhan, M., 2001. Effect of sewage sludge on the growth of maize crop. J. Biol. Sci. 1, 52-54.

REACH Annex XVII REACH Restricted Substance List 2019.

Rehman, RA., Rizwan, M., Qayyum, M.F., Ali, S., Rehman, M.Z., Zafar-ul-Hye, M., Hafeez, F., Iqbal, M.F., 2018. Efficiency of various sewage sludges and their biochars in improving selected soil properties and growth of wheat (Triticum aestivum L.). J. Environ. Manage. 223, 607-613. 
Rlöpffer, W., 1996. Environmental hazard assessment of chemicals and products. Part V. anthropogenic chemicals in sewage sludge. Chemosphere 33, 1067-1081.

Rodríquez-Rodríquez, C.E., Baron, E., Gago-Ferrero, P., Jelíc, A., Llorca, M., Farré, M., Diaz-Cruz, M.S., Eljarrat, E., Petrovíc, M., Caminal, G., Barceló, D., Vicent, T., 2012. Removal of pharmaceuticals, polybrominated flame retardants and UV-filters from sludge by the fungus Trametes versicolor in bioslurry reactor. J. Hazard. Mater. 233$234,235-243$.

Rodríquez-Rodríquez, C.E., Jelíc, A., Llorca, M., Farré, M., Caminal, G., Petrovíc, M., Barceló, D., Vicent, T., 2011. Solid-phase treatment with the fungus Trametes versicolor substantially reduces pharmaceutical concentrations and toxicity from sewage sludge. Bioresour. Technol. 102, 5602-5608.

Rodríquez-Rodríquez, C.E., Lucas, D., Baron, E., Gago-Ferrero, P., Molins-Delgado, D., Rodriguez-Mozaz, S., Eljarrat, E., Diaz-Cruz, M.S., Barceló, D., Caminal, G., Vicent T. 2014. Re-inoculation strategies enhance the degradation of emerging pollutants in fungal bioaugmentation of sewage sludge. Bioresour. Technol. 168, 180-189.

Rogers, H.R., 1996. Sources, behavior and fate of organic contaminants during sewage treatment and in sewage sludges. Sci. Total Environ. 185, 3-26.

Sahlström, L., Aspan, A., Bagge, E., Danielsson-Tham, A., 2004. Bacterial pathogen incidences in sludge from Swedish sewage treatment plants. Water Res. 38, 19891984.

Saleh Bairq, Z.A., Li, R.D., Li, Y.L., Gao, H.X., Sema, T., Teng, W.C., Kumar, S., Liang, Z.W., 2018. New advancement perspectives of chloride additives on enhanced heavy 
metals removal and phosphorus fixation during thermal processing of sewage sludge. J. Clean. Prod. 188, 185-194.

Samaras, V., Tsadilas, C.D., Stamatiadis, S., 2008. Effects of repeated application of municipal sewage sludge on soil fertility, cotton yield, and nitrate leaching. Agron. J. 100, 477-483.

Schowanek, D., Carr, R., David, H., Douben, P., Hall, J., Kirchmann, H., Patria, L., Sequi, P., Smith, S., Webb, S., 2004. A risk-based methodology for deriving quality standards for organic contaminants in sewage sludge for use in agriculture - conceptual framework. Regul. Toxicol. Pharmacol. 40, 227-251

Scott, M.J., Jones, M.N., 2000. The biodegradation of surfactants in the environment. Bioch. Bioph. Acta - Biomemb. 1508, 235-251.

Segneanu, A. E., Orbeci, C., Lazau, C., Sfirloaga, P., Vlazan, P., Bandas, C., Grozescu, I., 2013. Waste water treatment methods. In: Elshorbagy, W. (Ed.), Water Treatment. IntechOpen, DOI: 10.5772/53755, Available from: https://www.intechopen.com/books/water-treatment/waste-water-treatment-methods [Accessed 20.06.2019]

Seleiman, M.F., Santanen, A., Jaakkola, S., Ekholm, P., Hartikainen, H., Stoddard, F.L, Mäkelä, P.S.A., 2013a. Biomass yield and quality of bioenergy crops grown with synthetic and organic fertilizers. Biomass Bioenergy 59, 477-485.

Seleiman, M.F., Santanen, A., Kleemola, J., Stoddard, F.L., Mäkelä, P.S.A., 2013b. Improved sustainability of feedstock production with sludge and interacting mychorriza. Chemosphere 91, 1236-1242. 
Seleiman, M.F., Santanen, A., Stoddard, F.L., Mäkelä, P.S.A., 2012. Feedstock quality and growth of bioenergy crops fertilized with sewage sludge. Chemosphere 89, 12111217.

Seleiman, M.F., Selim, S., Jaakkola, S., Mäkelä, P., 2017. Chemical composition and in vitro digestibility of whole-crop maize fertilized with synthetic fertilizer or digestate and harvested at two maturity stages in boreal growing conditions. Agric. Food Sci. 26, $47-55$.

Simonich, S.L., Hites, R.A., 1995. Organic pollutant accumulation in vegetation. Environ. Sci. Technol. 29, 2905-2914.

Singh, R.P., Agrawal, M., 2008. Potential benefits and risks of land application of sewage sludge. Waste Manage. 28, 347-358.

Smith, S.R., 2009. Organic contaminants in sewage sludge (biosolids) and their significance for agricultural recycling. Philosoph. Trans. Roy. Soc. A 367, 3871-3872.

Smith, S.R., Riddell-Black, D., 2007. Sources and Impacts of Past, Current and Future Contamination of Soil. Final Report to DEFRA. Available from: file:///C:/Users/Home/Downloads/SP0547_7271_FRA.pdf [Accessed 10.05.2019].

Stevens, J.L., Northcott, G.L., Stern, G.A., Tomy, G.T., Jones, K.C., 2003. PAHs, PCBs, PCNs, organochlorine pesticides, synthetic musks, and polychlorinated $n$-alkanes in U.K. sewage sludge: survey results and implications. Environ. Sci. Technol. 37, 462467. 
773 Strauch, D., 1998. Pathogenic micro-organisms in sludge. Anaerobic digestion and

774

775

776

777

778 disinfection methods to make sludge usable as a fertiliser. Europ. Water Manage. 1, $12-26$.

Tchobanoglous, G., Burton, F.L., 1991. Wastewater Engineering Treatment: Disposal and Reuse, Third ed. McGraw Hill, New York.

Thomas, G.O., Farrar, D., Braekevelt, E., Stern, G., Kalantzi, O.I., Martin, F.L., Jones, K.C., 2006. Short and medium chain length chlorinated paraffins in UK human milk fat. Environ. Int. 32, 34-40.

U.S. Environmental Protection Agency. 8/18/2010. Nonylphenol (NP) and Nonylphenol Ethoxylates (NPEs). Action Plan. [RIN 2070-ZA09] https://webcache.googleusercontent.com/search?q=cache:elSjgYWHJpsJ:https://ww w.epa.gov/sites/production/files/2015-09/documents/rin2070-za09_npnpes_action_plan_final_2010-08-09.pdf $+\& \mathrm{~cd}=2 \& \mathrm{hl}=\mathrm{fi} \& \mathrm{ct}=\mathrm{clnk} \& \mathrm{gl}=\mathrm{fi}$

U.S. Federal Register, 1993. 40 CFR Part 503: Standards for the use and disposal of sewage sludge. Pp. 218-256.

Urbaniak, M., Wyrwicka, A., Tołoczko, W., Serwecińska, L., Zieliński, M., 2017. The effect of sewage sludge application on soil properties and willow (Salix sp.) cultivation. Sci. Total Environ. 586, 66-75.

Vamvuka, D., Dermitzakis, S., Pentari, D., Sfakiotakis, S., 2018. Valorization of Meat and Bone Meal through pyrolysis for soil amendment or lead adsorption from wastewaters. Food Bioprod. Process. 109: 148-157. 
Vanraes, P., Nikiforov, A.Y., Leys, C., 2016. Electrical discharge in water treatment technology for micropollutant decomposition, Plasma Science and Technology Progress in Physical States and Chemical Reactions, Tetsu Mieno, IntechOpen, DOI: 10.5772/61830. Available from: https://www.intechopen.com/books/plasma-science$\underline{\text { and-technology-progress-in-physical-states-and-chemical-reactions/electrical- }}$ discharge-in-water-treatment-technology-for-micropollutant-decomposition [Accessed 20.06.2019]

Wagner, G.J., 1993. Accumulation of cadmium in crop plants and its consequences to human health. Adv. Agron. 51, 173-212.

Wang, P., Menzies, N.W., Hongping, C., Yang, X., Mcgrath, S.P., Zhao, F., Kopittke, P.M., 2018. The risk of silver transfer from soil to the food chain is low after long-term (20 years) field applications of sewage sludge. Environ. Sci. Technol. 52, 4901-4909.

Wang, X., Chen, T., Ge, Y., Jia, Y., 2008. Studies on land application of sewage sludge and its limiting factors. J. Hazard. Mater. 160, 554-558.

Wen, G., Winter, J.P., Voroney, R.P., Bates, T.E., 1997. Potassium availability with application of sewage sludge, and sludge and manure composts in field experiments. Nutr. Cycl. Agroecosyst. 47, 233-241.

Wild, S.R., Jones, K.C., 1992. Organic chemicals entering agricultural soils in sewage sludges: screening for their potential to transfer to crop plants and livestock. Sci. Total Environ. 119, 85-119. 
814 Wołejko, E., Butarewicz, A., Wydro, U., Łoboda, T., 2014. Advantages and potential risks of municipal sewage sludge application to urban soil. Desalin. Water Treat. 52, 37323742.

Wong, J.W.C., Li, G.X., Wong, M.H., 1996. The growth of Brassica chinensis in heavymetal contaminated sewage sludge compost from Hong Kong. Bioresour. Technol. 58, $309-313$.

World Population Data Sheet, 2018. Population Reference Bureau. Available from: https://www.prb.org/wp-content/uploads/2018/08/2018_WPDS.pdf [Accessed date:

Xu, Y., Chen, Z., Ding, W., Fan, J., 2017. Responses of manure decomposition to nitrogen addition: Role of chemical composition. Sci. Total Environ. 587-588, 11-21.

Yan, S., Bala Subramanian, S., Tyagi, R.D., Surampalli, R.Y., 2009. Wastewater sludge characteristics. In:- Tyagi, R.D., Surampalli, R.Y., Yan, S., Zhang, T.C., Kao, C.M., Lohan, B.N. (Eds.), Sustainable Sludge Management: Production of Value Added Products. American Society of Civil Engineers, Virginia, pp. 6-36.

Zhao, S., Zhou,T., Wang, B., Zhu, L., Chen, M., Li, D., Yang, L., 2018. Different biotransformation behaviors of perfluorooctane sulfonamide in wheat (Triticum aestivum L.) from earthworms (Eisenia fetida). J. Hazard. Mater. 346, 191-198.

Zuo, W., Gu, C., Zhang, W., Xu, K., Wang, Y., Bai, Y., Shan, Y., Dai, Q., 2019. Sewage sludge amendment improved soil properties and sweet sorghum yield and quality in a newly reclaimed mudflat land. Sci. Total Enviro. 654, 541-549. 